\title{
307 大気圧非平衡プラズマにおける然料電池水素オフガスの酸化機構
}

Oxidation Mechanisms of Hydrogen Off-gas from Fuel Cells by Atmospheric Non-equilibrium Plasma

○学 古谷野 文香 (岐阜大) 正 神原 信志 (岐阜大) 学 阿部 将典 (岐阜大)

Ayaka KOYANO, Gifu University, Graduate School, 1-1 Yanagido, Gifu, Japan Shinji KAMBARA, Gifu University Masanori ABE, Gifu University

\begin{abstract}
The removal of hydrogen in off-gas from fuel cells is desired to be safely processed. In the present research, simulated molecular hydrogen gas mixed with oxygen and nitrogen gases was directly removed in an intermitt ent dielectric barrier discharge (DBD). Hydrogen was oxidized even in a temperature lower than $100{ }^{\circ} \mathrm{C} . \mathrm{A}$ hy drogen conversion rate of approximately $100 \%(98.8 \%)$ was obtained at a consumes power of $1.2 \mathrm{~kW}$ for a ga $\mathrm{s}$ temperature of $80{ }^{\circ} \mathrm{C}$. When oxygen concentration was increased, NO was obtained as a by-products. But $\mathrm{N}$ $\mathrm{O}$ was reduction by increase of equivalence ratio. Their reaction mechanism was investigated at simulation wit h elementary reactions of $\mathrm{H} / \mathrm{O}$ systems.
\end{abstract}

Key Words: Hydrogen, Oxidation, Radical, Fuel cell, DBD

\section{1. 緒言}

水素は化石エネルギーやバイオマス, 廃车物など多様な炭 化水素系資源や太陽エネルギーから製造でき，エネルギー利 用においては，高効率かつ低環境負荷であるという特徵をも つことから，エネルギーキャリアとしての水素利用が有望視 されている。自動車交通にかかわるエネルギ一・環境問題に おいても，その解決手段として水素を利用した燃料電池自動 車 (FCV) の普及に期待が高まっている。世界の自動車保有 台数は, 2000 年時の約 8 億台から 2030 年には 15 億台まで増 加すると予想され，省エネルギーおよび環境負荷低减のため の研究開発や法令による種々の規制がなされる一方で, より 深刻なエネルギー・環境問題に発展する可能性があり, FCV への期待は大きい。

しかし，FCV の本格的普及におかては，水素に対する十分 な安全対策が必要となる. FCVに用いられる固体高分子形然 料電池（PEFC）では，水素を過剩に供給し，それを再循環す ることで水素利用率と発電効率を高めているが，水素再循環 系内に混人する䇪素や水などの不純物を除去するために， 時々，それらを系外に排出しなければならない。この排ガス は水素オフガスと呼ばれ，その水素濃度は $90 \mathrm{vol} \%$ を超える こともある。水素の爆発範用は 4-75\%（空気中）と非常に 広いため, FCVにおいては水素オフガスの適切な処理が必要 とされる ${ }^{(1-2)}$ 。
水素オフガスの処理は，触媒による燃焼処理，空気による 希釈排気，バーナ一を用いる燃焼処理が提案されている。触 媒燃焼法は，水素を完全燃焼するため安全な姏理方法である が，白金触媒を使うためコスト面で難がある。また空気希釈 方法は，コスト面で優位ではあるが，水素爆発のリスクは免 れない。バーナ一燃焼法は水素の完全処理とコストを両立す る技術の1つではあるが，燃焼安定性や車載性に難がある。

そこで，我々は誘電体バリア放電(DBD)による大気圧非平 衡プラズマで水素を酸化処理する方法について検討してい る。この方法は, 装置が小型で単純であること, 触媒を使わ ないこと, 水素を完全酸化できることから, コスト面, 安全 面, 車載性に優れた方法と言える ${ }^{(3-4)}$ 。

本研究の最終目的は, 大気圧非平衡プラズマによる実用的 な水素酸化処理装置の開発である。これまでに, $\mathrm{H}_{2} / \mathrm{O}_{2} / \mathrm{Ar}$ 混 合気体での水素酸化特性を調べ, DBD の直接処理で水素を高 効率に処理できることとその反灾メカニズムを報告した ${ }^{(3)}$ 。

本報告では，実際の水素オフガス組成である $\mathrm{H}_{2} / \mathrm{O}_{2} / \mathrm{N}_{2}$ の混 合気体を用いて, 印加電圧, 周波数, 処理時間, ガス温度が 水素酸化率や副生成物に及ぼす影響について実験を行った。

\section{2. 実験装置および実験方法}

Fig.1 に実験装置の概略図を示す。反応器は長さ $300 \mathrm{~mm}$ の 円筒二重管型構造の石英管である。内側には, 高電玨電極(直

〔№.09-13] 日本機械学会第 19 回環境工学総合シンポジウム 2009 講演論文集〔2009.7.9〜11・那覇 
径 $50 \mathrm{~mm}$, 長さ $275 \mathrm{~mm}$ ), 外側には接地電極(厚さ $0.2 \mathrm{~mm}$, 長さ $200 \mathrm{~mm}$ ) 配置した。内管と外管との隙間(gap 長)は $1.5 \mathrm{~mm}$ である。供給ガスは，マスフローコントローラーとガ スブレンダーを用いて $\mathrm{H}_{2}, \mathrm{O}_{2}, \mathrm{~N}_{2}$ の混合気体とし， $\mathrm{N}_{2}$ をべ 一スガスとして実験を行った。実際の FCVs で排出される水 素濃度は $90 \mathrm{vol} \%$ 以上であるが，大気中での水素の燃焼限界 は約 4 vol\%であることから, 安全面を考慮して水素濃度を 2.0 vol\%とした。反応管の出口で熱電対( Type K ) を用いてガス温 度を測定し，ガスクロマトグラフィー(Aglient 3000A)によっ て $\mathrm{H}_{2}, \mathrm{O}_{2}$ 濃度を測定した。大気圧非平衡プラズマは, 高周 波電源(ハイデン研究所製, PHF-2KL)を用いて発生させた。

Fig .2 に, 高周波電源(OCS)の正弦波 2 波からなる 2 周期の パルス波形を示す。測定には高電圧プローブ(Tektronix 社製, P6015A) とオシロスコープ(Tektronix 社製-TDS3034B)を用い た。印加電圧 $V_{\mathrm{pp}}$ は，波形のピークーピークで定義した。 $T_{0}$ は 波形保持時間， $T_{1}$ はパルス間隔である。周波数 $R_{\mathrm{R}}$ は $T_{1}$ の逆 数とした。

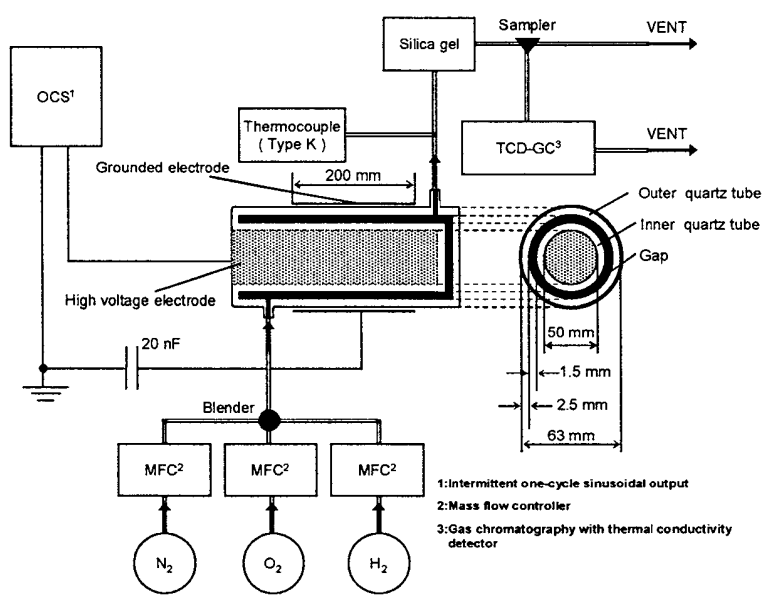

Fig.1 Experimental setup of the DBD reactor for hydrogen oxidation.

実験条件を Table 1 に示す。Condition I では, 印加電圧, 周 波数, 流量を変えることによって基本的な特性, エネルギー 密度を調べた。Condition II では, 酸素濃度を変えることによ って当量比の影響を調べた。

なお，水素転換率，エネルギー密度は次式のように定義した。

$$
X_{h}, \%=\frac{\left[\mathrm{H}_{2}\right]_{\mathrm{i}}-\left[\mathrm{H}_{2}\right]_{\mathrm{o}}}{\left[\mathrm{H}_{2}\right]_{\mathrm{i}}} \times 100
$$

ここで, $\left[\mathrm{H}_{2}\right] \mathrm{i}$ は入口の水素濃度, $\left[\mathrm{H}_{2}\right] \mathrm{o}$ は出口の水素濃度で ある。

$$
E_{d}=\frac{1000 \cdot P}{V} \times \theta
$$

ここで, $P$ は投入電力 $[\mathrm{kW}], V$ は DBD 領域の反応器 体積 $\left[\mathrm{cm}^{3}\right], \theta$ は DBD 領域における反忘器内滞留時間 [s]である。

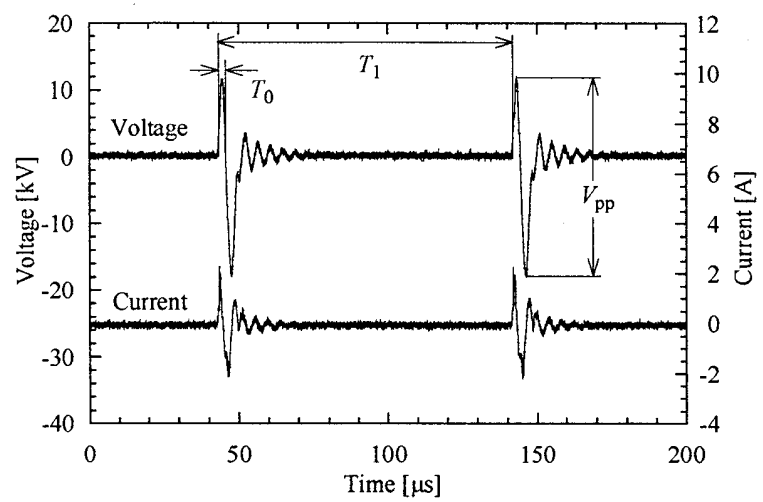

Fig. 2 Waveform of the applied voltage and the current. (Flow rate of $\mathrm{N}_{2}$ gas $=4 \ell / \mathrm{min}, V_{\mathrm{pp}}=30 \mathrm{kV}, I=4.5 \mathrm{~A}, R_{\mathrm{R}}=10 \mathrm{kHz}$, $\left.T_{0}=10 \mu \mathrm{s}\right)$

\begin{tabular}{|c|c|c|c|}
\hline Condition & & I & II \\
\hline Voltage, $V_{\mathrm{PP}}$ & {$[\mathrm{kV}]$} & $25,30,32$ & 30 \\
\hline Frequency, $R_{\mathrm{R}}$ & {$[\mathrm{kHz}]$} & $7,10,15$ & 10 \\
\hline Discharged Power, $P$ & [kW] & $0.26-0.68$ & $0.47-0.52$ \\
\hline $\begin{array}{l}\text { Gas Temperature } \\
\text { Total gas flow rate }\left(N_{2} \text { balance }\right.\end{array}$ & $\begin{array}{r}\left.{ }^{\circ} \mathrm{C}\right] \\
{[\theta / \min ]}\end{array}$ & $\begin{array}{l}25-80 \\
48.12\end{array}$ & $\begin{array}{c}25-80 \\
8\end{array}$ \\
\hline $\begin{array}{l}\text { Residence time } \\
\mathrm{H}_{2} \text { concentration }\end{array}$ & $\begin{array}{r}{[s]} \\
{[\mathrm{vol} \%]}\end{array}$ & $\begin{array}{c}0.19-0.67 \\
2.0\end{array}$ & $\begin{array}{c}0.28-0.33 \\
2.0\end{array}$ \\
\hline $\mathrm{O}_{2}$ concentration & [vol\%] & 1.0 & $20,4.0,2.0,1.0,0.5$ \\
\hline Equivalence ratio, $\phi$ & {$[-]$} & 1.0 & $0.05,0.25,0.5,1.0,2.0$ \\
\hline
\end{tabular}

Table 1 Experimental conditions

\section{3. 実験結果}

\section{1 水素酸化の基本特性}

Fig. 3 は, $R_{\mathrm{R}}=10 \mathrm{kHz}, V_{\mathrm{pp}}=30 \mathrm{kV}$ としたときの処理時 間に対する排ガス中の水素, 酸素および一酸化窒素の濃 度, ガス温度, 水素転換率の変化である。 $2.0 \mathrm{vol} \%$ の水素 は $1700 \mathrm{~s}$ で $0.09 \%$ になり（水素転換率 $X_{\mathrm{h}}=96 \%$ ）, DBD により水素の酸化処理が可能であることがわかった。

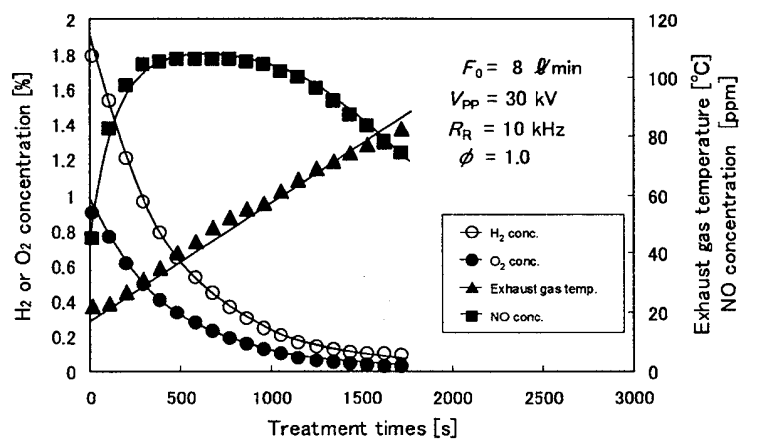

Fig.3 Fundamental characteristics of hydrogen oxidation. 
一方, 反応器出山のガス温度に着目すると, プラズマ点 灯からの時間経過に対し比例的に上昇している。これは, 高電圧電極に発生したジュール熱が石英ガラスや排ガス に伝熱したためであると考えられる。ガス温度の上昇につ れて水素転換率も上昇しているようである。NO 生成濃度 の変化は単調ではないが，最大 $106 \mathrm{ppm}$ を生成した。

\section{2 エネルギー密度による整理}

Fig.4 に, Table 1 に示した Condition I の条件における水 素転換率の変化をエネルギー密度に対してプロットした。 パラメータはガス温度である。これより，エネルギー密度 の増加によって水素転換率は急激に上昇することが分か る。これは, エネルギ一密度の増加によって水素及び酸素 ラジカルの生成量が増加し, 水素酸化反応を促進させたた めであると考えられる。また, 温度の上昇においても水素 転換率が増加しており，こちらも水素酸化反応が促進され たためであると考えられる。

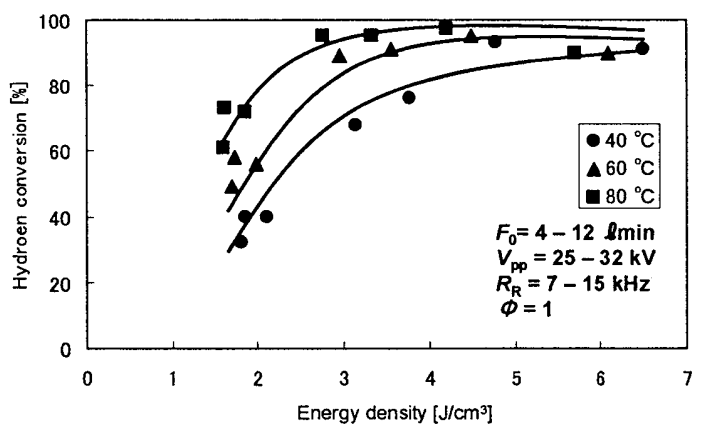

Fig.4 Hydrogen conversion at different gas temperatures as a function of the discharge power.

\section{3 副生成物}

本実験は窒素をベースガスとしているため副生成物と してNO が生成される。過剩な酸素分子が一酸化窒素の生 成の要因であると推定される。そこで，投入した水素 $(2.0$ vol\%）を酸化するのに必要な理論酸素量の比率の逆数，す なわち当量比を変化させて実験を行った。

Fig. 5 は, 当量比に対寸る NO 生成濃度の変化をガス温度 をパラメータとして示した。当量比 $\phi=1.0$ で理論酸素量, 1.0 未満で過剩酸素，1.0 以上で酸素不足雰囲気である。 $\phi$ の増加にともない $\mathrm{NO}$ 生成濃度は減少し， $\phi=2.0$ では NO 濃度はわずか $3-5 \mathrm{ppm}$ となった。

したがって，DBD による水素の酸化処理装置では，当 量比が大きな条件とし, いくつかの反応器を直列につない で処理する方法が有効と考えられる。

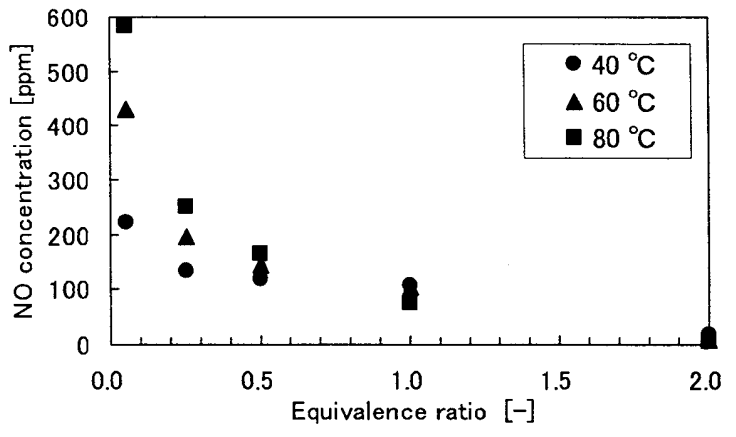

Fig.5 Effect of equivalence ratio on NO formation at various exhaust gas temperature.

\section{4. 素反応解析}

\section{1 素反応式と計算方法}

水素燃料燃焼における水素酸化の速度論的研究は多く 行われている。その中でも幅広い燃焼条件に適用できる Li らのメカニズム ${ }^{(5)}$ を，また，NOx 生成の素反応計算に は Glarborg のメカニズム ${ }^{(6)}$ を用い，両者を組み合わせて DBD 内の水素酸化と NOx 生成に関し素反忘計算を行っ た。計算には，汎用の化学反応解析ソフトウェアである CHEMKIN-PRO を使用した。

反応器モデルには完全混合反応器(PSR)を用い，初期条 件に水素及び酸素ラジカルの濃度を与えた。水素及び酸素 ラジカル濃度の推算は, Penetranteらのによって提案され た G-Value（100eV あたりに生成するラジカルの個数）を 用いて行った。Fig.6に，DBD 一の投入電力に対する $\mathrm{H} ま$ たは $\mathrm{O}$ ラジカルの生成モル分率の計算結果を示寸。投入電 力の増加によって各ラジカルの生成量は増加する。この推 算值を初期值として与え, 水素酸化と NOx 生成について 計算解析を行った。

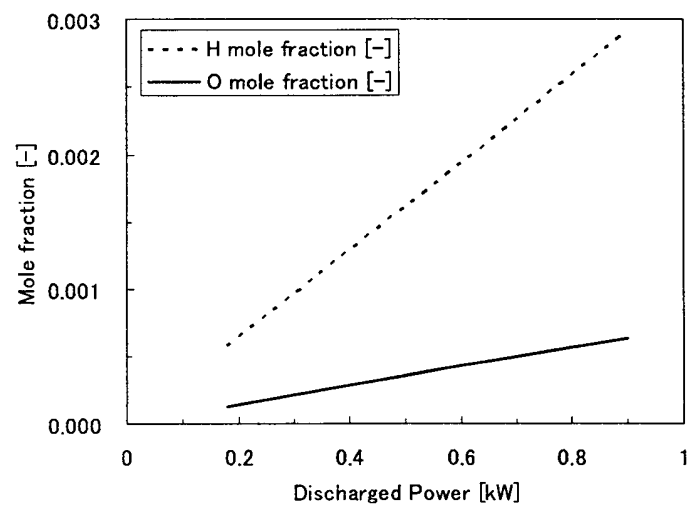

Fig.6 Estimated $\mathrm{H}$ and $\mathrm{O}$ radical mole fractions at various discharge powers. 


\section{2 解析結果}

Fig. $7 に \phi=1.0$, 流量 $8 \ell / \mathrm{min}$, 投入電力 $180 \mathrm{~W}-900 \mathrm{~W}$ における水素転換率の計算結果を示寸。温度上昇, 電力の 増加によって DBD 処理により水素転換率が増加し, Fig.4 の傾向を説明できる。ただし，実験と計算では，反応温度 が大きく異なる。実験では，DBD 反応器出ロガス温度を 測定しており，これは DBD 反応場の温度よりも低いこと が十分予想される。Nozaki ら ${ }^{(8)}$ は, 非平衡プラズマによる メタン改質反応場の温度は $300^{\circ} \mathrm{C}$ 近く上昇することを示して いることから，本実験での反応場の温度もまた Fig.7 のよう な温度に近くなっているかも知れない。

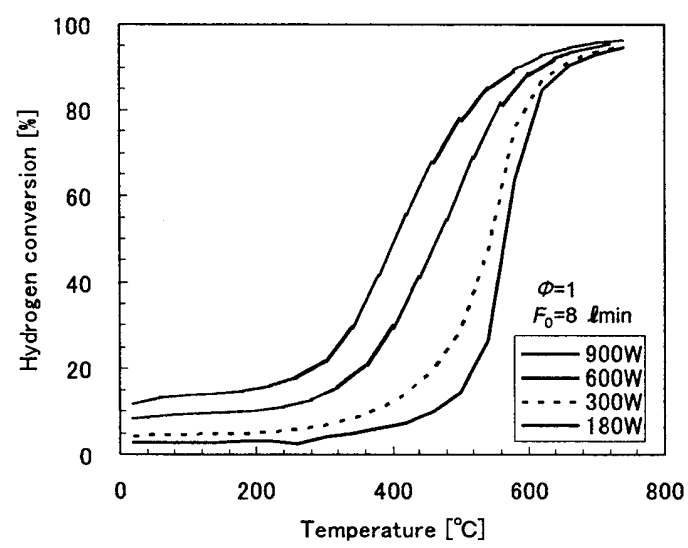

Fig.7 Simulation result of hydrogen oxidation in the DBD.

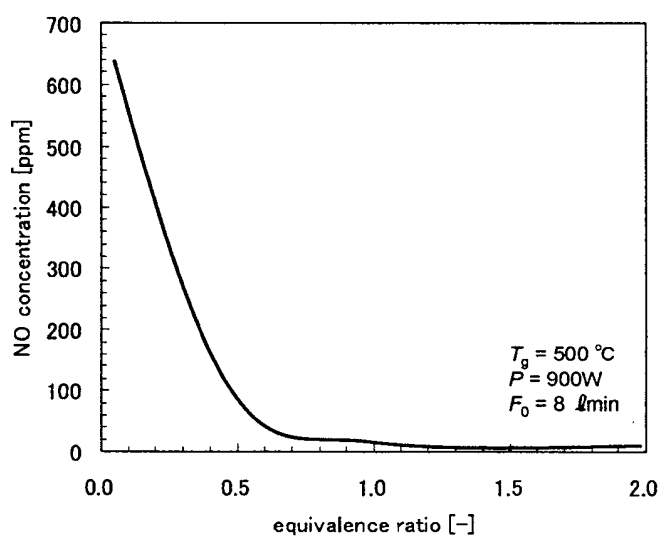

Fig.8 Variation of NO concentration with equivalence ratio.

次に, 温度 $500^{\circ} \mathrm{C}$ とた時の当量比に対する $\mathrm{NO}$ 濃度の計 算結果を Fig.8 に示す。当量比の增加につれて NO 濃度は低 下し，Fig.5 に示した実験結果の傾向を説明できる。 DBD 内では高い電子エネルギーにより， $\mathrm{N}_{2}, \mathrm{O}_{2}, \mathrm{H}_{2}$ 分子の 一部が解離し，それぞれ N, O, H ラジカルを生成する（Fig. 6)。生成するラジカル濃度は電子エネルギ一，すなわち投入 電力とガス分圧に依存する， $\phi<1.0$ では，比較的濃度が高
いH ラジカルと O ラジカルが反応し OH ラジカルを生成し, $\mathrm{H}_{2}$ の酸化に寄与する。しかし，この $\mathrm{OH}$ は以下の反忘で NO も生成する。

$$
\mathrm{N}+\mathrm{OH} \rightarrow \mathrm{NO}+\mathrm{H}
$$

また，次の反応によっても NO を生成する。

$$
\begin{aligned}
& \mathrm{N}_{2}+\mathrm{O} \rightarrow \mathrm{NO}+\mathrm{N} \\
& \mathrm{N}+\mathrm{O}_{2} \rightarrow \mathrm{NO}+\mathrm{O}
\end{aligned}
$$

一方， $\phi>1.0$ では, $\mathrm{OH}$ ラジカルは $\mathrm{H}_{2}$ の酸化に使用され, (5) の反応は起こらない。そのため高当量比側で NO の生成が抑 制されたものと考えられる。

\section{5. 結言}

燃料電池自動車からの水素オフガスを安全, 安価に処理 する装置を開発するために, 大気圧非平衡プラズマによる 水素酸化の挙動を $\mathrm{H}_{2} / \mathrm{O}_{2} / \mathrm{N}_{2}$ 混合ガスを用いて調べた。この 方法では, 反応器出口温度 $80^{\circ} \mathrm{C}$ 程度の低温で水素をほぼ完 全に酸化することが可能である。投入電力およびガス温度 の增加に伴って水素転換率は上昇した。

$\mathrm{H}_{2} / \mathrm{O}_{2} / \mathrm{N}_{2}$ 混合ガスでの水素酸化処理では, 副生成物とし てNO が生成した。NO生成には酸素濃度が強く影響し, 当量比を 2.0 にすると NO 生成は見られなくなった。

DBD による水素酸化の反忘機構を考察するために，水 素及び酸素ラジカルの生成量を推定し，Li らと Glarborg らの素反応メカニズムを組み合わせ, 完全混合反応器モデ ルで計算解析を行った。温度および投入電力の増加によっ て水素転换率は上昇し, 一方, 当量比の増加はNO の生成 が抑制されることが素反応計算で得られた。

謝辞 本研究は財団法人東海産業技術振與財団による助 成を受けて行われた。ここに謝意を表する.

参考文献

1) J. Romm: Energy Policy 34 (2006) 2609-2614.

2) S. Kawatsu: J. of Jpn. Inst. of Energy 82 (2003) 180-184 [in Japanese].

3) T. Osakabe, S. Kambara, R. Kuriyama, A. Koyano, K. Yukimura, H. Moritomi, J. Comb.Soc. Japan 50 (2008) 136-144 [in Japanese]..

4) S. Kambara, R. Kuriyama, T. Osakabe, K. Yukimura, Int. J. Hydrogen Energy 33 (2008) 6792-6799.

5) Li, J., Zhao, Z., Kazakov, A., Dryer, F., Int.J.Chem.Kinetics.36: 566-575(2004).

6) P. Glarborg, M. U. Alzueta, K. Dsm-Johansen, J. A. Miller: Combust Flame 115 (1998).

7) Penetrante, B. M., Non-Thermal Plasma Techniques for Pollution Control, Springer-Verlag, berlin GDR, 65-89(1993).

8) Nozaki, T., Unno, Y.,Miyazaki, Y.,Okazaki, K.,J.Phys.D;Appl.Phys.34:2504-2511. 